\title{
Teaching with Adult Learners: Peer-Assessment Software in Translation and Interpretation
}

\author{
Nur Aisyah Zulkifli, M.Zaim, Syahrul.R, Agustina \\ UIN Suska Riau-Indonesia, Universitas Negeri Padang-Indonesia \\ nur'aisyah.zulkifli@uin-suska.ac.id
}

\begin{abstract}
PowerPoint is one of the presentation software programs used effectively to present material in the classroom and encourage learner learning. In this study, PowerPoint is used as media to support learners' peer-Assessment in the classroom. This case study highlights learners' perception about the effectiveness of PowerPoint software as learners' peer assessment tool implemented in translation and interpretation subject. fifty seven learners from two classes of English Education Department were surveyed. Age (adult learners) considerations may be worthy of note with regard to learner views of assessment. Survey was divided into three sections; 1) the use of PowerPoint as peer-assessment media; 2) being a rater/ being rated by peers, 3) Interview. Survey response data indicated that a majority of learners had a positive reaction to the use of PowerPoint slide as tool to support peerassessment, yet also expressing some weaknesses using this software for peer-assessment.
\end{abstract}

Keywords-Adult learners; PowerPoint; Peer-Assessment; Translation and Interpretation subject.

\section{INTRODUCTION}

Teaching adult or known as andragogy (Christian, 2015) is defined as the art and science of helping adults learn (Knowles, 1980). University learner involved adult learner. Lecturer as facilitator of adult learners should know the concept of adult learning theory to help them achieve learning objective. In 1984, Knowles suggested four principles that are applied to adult learning: 1) Adults need to be involved in the planning and evaluation of their instruction, 2) Experience (including mistakes) provides the basis for the learning activities, 3) Adults are most interested in learning subjects that have immediate relevance and impact to their job or personal life, 4) Adult learning is problem-centered rather than contentoriented (Kearsley, 2010).

The first principle mentions that adults need to be involved in evaluation. Peer assessment is as a tool to engage learners in the evaluation process (Alzaid, 2017). The advantages using peer assessment in evaluation (Lutze-Mann, 2015 \& Ross 2006): 1) provides consistent results across the evaluation criteria and tasks in short period of time; 2) giving information about learner achievement that corresponds in part with the information resulting from the evaluation of teachers, as it leads to higher learner achievement; 3) contributing in enhancing strengths through training learners on how to evaluate their work. 4) Involving learners in the learning process and developing their ability to think critically; 5) Learning from of critical evaluation and feedback from others; 6) Developing social skills such as cooperative learning. Peer assessment is used to enhance learning as an effective way to increase motivation for learners by engaging them in the evaluation process (Rimer, 2007).

Peer assessment is a mutual process between learners (Spiller, 2009).It allows learners work in team or small group discussion. They can help each other to make sense of the gaps in their learning and understanding and to get a more sophisticated grasp of the learning process. Learners saw peer assessment as a positive experience that aided in their understanding of the assessment process (Bloxham and West, 2004). It encourages learners to reflect on their role and contribution to the process of team work. The aim of peer-assessment is giving the improvement and revision to learners work.

PowerPoint is one of the presentation software programs used effectively to present material in the classroom and encourage learner learning. In this study, PowerPoint as a software is used as media to support learners' peer-assessment in the classroom. By utilizing PowerPoint in peer assessment learners can look at their work directly in front of class, and judge their competence, can assess the quality of their work and revise it based on the criteria score/rubric. The benefits of using PowerPoint are lecture more highly than those without slide (Drouin, et al. 2013), higher ratings to learner course and self-efficacy (Suskind, 2005). From PowerPoint slide learners are able to independently assess their own and other learners' ability. It supports learners to identify their next learning steps.

Translation is a subject learned by adult learners at university. Translation is not only studied as a science but also as assessment, or translation assessment. According to Angelelli (2009), the concept of translation assessment may or may not include translation, editing, and proofreading as separate tasks requiring different skills, and therefore different measurements. Therefore, in the classroom, learners learn both theory and practice in translation. The product of students 
practice involved translation assessment. Cohen (1994) in in American Translators Association Scholarly Monograph Series (ATA) stated guiding question for translation assessment:

1. What aspects of an individual's translation ability should be assessed?

2.Why are certain techniques, assessment methods or approaches being used instead of others?

3.How will the assessment instruments be developed, and how are they going to be validated?

4.When will the test take place, and how often is the professional organization planning to administer it?

5.Where will the exam take place and what is the physical environment(s) of the exam?

6. Who is the intended audience for the test?

7. What information is available about social backgrounds cognitive skills and personal characteristics (diverse or similar) of target audience?

8.For whom are the results on the translation test intended; for candidates them-selves or for organizations which make the exam a requirement

\section{METHODS}

This case study investigated learners' perception about the use of PowerPoint software as learners' peer-Assessment tool in teaching translation and interpretation subject. Translation and interpretation is one of subjects taught at English Education Department of UIN Suska Riau. Learners study this subject at fourth semester ( 8 credit semesters).The objective of this subject is learners are able to translate words in context, different types of sentences, and short texts of different purposes. The aim of the course is to acquire insight into basic translation procedures through practical experience, and to master basic translation skills. Lasting from September-December, the particular course discussed in this case study included two classes of fourth-semester learners, numbering 57 in total. Learners were approximately $20-21$ years old. Age considerations may be worthy of note with regard to learner views of assessment. To collect the data, learner survey was distributed and completed by 57 learners.

Research question: How effective are PowerPoint presentation as learners' peer assessment tool implemented in translation and interpretation subject?

\section{FINDING AND DISCUSSION}

In this study, Learners PowerPoint presentation was product of translation practice (task). Learner activities were; 1) comprehension of the source-language text, 2) translation techniques and 3) writing in the target language. The evaluation of learner PowerPoint is a form of performance-based assessment. These involved the learners demonstrating to an audience about their understanding and implementation of translation knowledge and skills. Learners perform a task and show specific skills and competencies called performance-based assessment (Stiggins, 1987).

Learners are expected to be able have transfer competence and communicative translational competence in learning translation and interpretation. Transfer competence is defined as the "the ability to complete the transfer process from the source language to the target language text, taking into account the translation's function and the characteristics of the receptor" (Orozco 2000). Colina (2003) defines communicative translational competence as consisting not only of communicative competence in both languages, but also including an element of interlingual and intercultural communicative competence. The materials learned by the learners in this study can be seen on appendix.

The procedure of using PowerPoint as media to support learners' peer-Assessment in teaching Translation and Interpretation subject was:

First meeting, (conditioned)

1.Learners divided into groups (5-6 persons), it may individual.

2.Learners got module of translation and interpretation subject

3.Learners worked in peers to understand the concepts of translation (a translation material/topic based on the syllabus). It was conducted through small group discussion, one group became presenter in front of class and others were audiences.

Second meeting,

1.Learner(s) didtranslation practice to develop their ability to become translators through task.

2.Learner(s) activity was first, comprehension of the source-language text, second, translation techniques and third, writing in the target language.

3.The result of learners tasks would be showed in PowerPoint Slide

4.Peer rating sheets (translation rubric created by lecturer) were distributed to all learners. This peer rating sheet refers to translation topic/task. So, different topic/task may have different translation rubric.

5.Learners performed their presentation using the PowerPoint 
6.During the presentation, others learners have responsibility as peer rater to fill out peer rating sheet

7.Sheets were collected at the end of class and given to the lecturer to be discussed

During this study, the procedure of using PowerPoint as media to support learners' peer-Assessment in the classroom had been implemented for four months. This has been conducted as many as twelve meetings. It was observed directly by the writer as lecturer of Translation and Interpretation subject at English Education Department of UIN Suska Riau. To gauge learner perceptions of using PowerPoint as media to support learners' peer-Assessment, learner survey was distributed and completed by 57 learners. White (2009) was divided the survey into three sections: being a rater/ being rated by peers, peer-assessment process and additional comments (open-ended). In this study, survey carried out into 1) the use of PowerPoint as peer-assessment media; 2) being a rater/ being rated by peers, 3) Interview. Five-point Liker scale was used on the survey to gauge opinions: strongly agree, agree, neither agree nor disagree, disagree, strongly disagree.

From the result of survey, it was found that 31 learners (54.39\%) strongly agreed interesting using PowerPoint Slide for peer-assessment. They said so far peer-assessment has been applied. But it was only giving correction for some peer translation task. It did not cover all learner translation practice in the classroom. It took a lot of time, because we had to write the answer on the whiteboard interchangeably. In addition, 29 learners $(50.88 \%)$ agreed that using of PowerPoint software provided peer-assessment as visual framework. PowerPoint slides helped keep peer-assessment organized. All this time, PowerPoint was used as teaching media to present translation material, peer-assessment lead by lecturer as facilitator then many learners asked question to make sure their correction was accepted. The same question may be asked by different learners. It was not organized well.

Unfortunately, the result of agree about PowerPoint Slide-Show created by learners showed less than $45 \% .17$ learners (29.82\%) agreed synchronization of PowerPoint Slides assisted peer-assessment items sheet. 20 learners $(35.09 \%)$ agreed PowerPoint content facilitated peer-assessment steps. 15 learners (26.32\%) agreed clear order between PowerPoint and peer-assessment sheet motivated to complete assignment. Based on the result of interview, they suggested that there must be clear standard in creating PowerPoint slide-show for translation task. Lecturer has made good standard of appraisal to assess learner translation (peer rating sheet), yet it has not set clear standard for PowerPoint. It was supported by the result that 11 learners $(19.30 \%)$ neither agree nor disagree PowerPoint slide and Assessment sheet were simple and uncomplicated.

Overall, survey response data indicated that a majority of learners had a positive reaction to the use of PowerPoint slide as tool to support peer-assessment, yet also expressing some weaknesses use this software for peer-assessment. From the interview, learners feel comfortable in peer-assessment process because PowerPoint promote ideas associated with assessment for learning. It has different with the peer assessment that only uses whiteboard as media. Whiteboard cannot display image, sound, and video related to learners task. In addition, they were more autonomous in learning translation and interpretation subject. Peer assessment helps learners to become more autonomous (White, 2009). It allows lecturers to share the evaluation of assignments with their learners. It is grounded in theories of active learning (Piaget, '71), adult learning (Cross, '81) and social constructionism (Vygotsky, '62).

\section{CONCLUSION}

Assessment is at the heart of learner experience (Brown and Knight, 1994). Using PowerPoint as media of peerassessment can help learners evaluate their ability simultaneously through the projection of: color, images, video and shapes for visual learners; sound and music for auditory learners; and interactive slides which ask learners to do something for kinesthetic learners. If you want to change learner learning change the method of assessment (Brown, Bull \& Pendlebury, 1997). It supports adult learners who wanted to learn autonomous.

For teacher or lecturer who want to use PowerPoint as media to support peer-assessment in teaching translation and interpretation subject or other, you should make clear standard in order the product of learners task is not vary. Teacher or lecturer is considered to be able to give a good rating to their learner, yet learners need standard assessment to assess their peers. This case study may also have been and will happen in your classroom.

\section{References}

American Translators Association Scholarly Monograph Series (ATA), Volume XIV Testing and Assessment in Translation and Interpreting Studies, Edited by Claudia V. Angelelli and Holly E. Jacobson

Angelelli, C. V., \& H. E. Jacobson (eds.) (2009) Testing and Assessment in Translation and Interpreting Studies. A call for dialogue between research and practice.vi, 386 pp.Expected October 2009. American Translators Association Scholarly Monograph Series (ATA), Volume XIV 
Alzaid, J. M. (2017) The Effect of Peer Assessment on the Evaluation Process of Learners. International Education Studies; 10 (6), 2017 ISSN 1913-9020 E-ISSN 1913-9039 Published by Canadian Center of Science and Education

Christian Eugene Ekoto, P. (2015) The Impact of Andragogy on Learning Satisfaction of Graduate Learners. American Journal of Educational Research 3 (11), 2015, pp 1378-1386. http://pubs.sciepub.com/education/3/11/6/

Colina, S. (2003) translation Teaching from research to the classroom a handbook for teachers. Boston: McGraw-Hill Companies.

Drouin, M., Hile, R. E., Vartanian, L. R., \& Webb, J. (2013).“ Learner Preferences for Online Lecture Formats.” Quarterly Review of Distance Education, 14(3), 151-162.

Knowles, M. S. (1980). The modern practice of adult education: From pedagogy to andragogy. Englewood Cliffs, NJ: Cambridge Adult Education.

Kearsley, G. (2010). Andragogy (M.Knowles). The theory into practice database. Retrieved from http://tip.psychology.org/

Lutze-Mann, L. (2015). Peer Assessment of Assignment Drafts: About Peer Assessment. Assessment Toolkit, Learner Peer Assessment. Retrieved from https://teaching.unsw.edu.au/peer-assessment

Orozco, M. (2000) "Building a Measuring Instrument for the Acquisition of Translation Competence in Trainee Translators.'In Developing Translation Competence, 199-214.

Rimer, S. (2007). Harvard task force calls for new focus on teaching and not just research. The New York Times. Retrieved from https://www.nytimes.com/2007/05/10/education/10harvard.html

Ross, J. (2006). The Reliability, Validity, and Utility of Self-Assessment, Practical Assessment Research \& Evaluation, 11 (10).1-13.

Spiller, D. (2009). Assessment Matters: Self-Assessment and Peer Assessment. Teaching Development, The University of Waikato. Retrieved from https://www.waikato.ac.nz/teaching-and-learning/teachingdevelopmentpdf/booklets/8_SelfPeerAssessment.\%20pdf

Susskind, J. E. (2005). "PowerPoint's Power in the Classroom: Enhancing Learners' Self-Efficacy and Attitudes." Computers \& Education, 45(2), 203-215.

White, E. (2009) Learner Perspectives of Peer Assessment for Learning in a Public Speaking Course. Asian EFL Journal Professional Teaching Articles.Vol. 33. January 2009 